\title{
Stock Price Predictability of Financial Ratios and Macroeconomic Variables:
}

\section{A Regulatory Perspective}

\author{
Seung Woog Kwag \\ Division of Business Administration, College of Economics and Business Administration, \\ Sookmyung Women's University, Seoul, Korea \\ Yong Seog Kim* \\ Department of Management Information System, Jon M. Huntsman School of Business, Utah State University, \\ Logan, UT, USA
}

(Received: August 7, 2013 / Revised: October 26, 2013 / Accepted: November 10, 2013)

\begin{abstract}
The present study examines a set of financial ratios in predicting the up or down movements of stock prices in the context of a securities law, the Sarbanes-Oxley Act of 2002 (SOA), controlling for macroeconomic variables. Using the logistic regression with proxy betas to alleviate the incompatibility problem between the firm-specific financial ratios and macroeconomic indicators, we report evidence that financial ratios are meaningful predictors of stock price changes, which subdue the influence of macroeconomic indicators on stock returns, and more importantly that the SOA truly improves the stock price predictability of financial ratios for the markup sample. The empirical results further suggest that industry and time effects exist and that for the markdown sample the SOA actually deteriorates the predictive power of financial ratios.
\end{abstract}

Keywords: Financial Ratios, Macroeconomic Variables, Sarbanes-Oxley Act, Proxy Beta, Logistic Regression

* Corresponding Author, E-mail: yong.kim@usu.edu

\section{INTRODUCTION}

As the market participants analyze equity securities for trading, they take advantage of financial ratios and macroeconomic indicators to evaluate whether a firm of interest shows an improvement in the future periods. The main reason is that the operational efficiency and effectiveness are reflected in the financial ratios and the sustainable growth in earnings depends on macroeconomic conditions. Since the corporate level efficiency and growth are foundations of economic stability, securities laws, and regulations have been designed to facilitate them. For instance, the Sarbanes-Oxley Act of 2002 (SOA) is one of the most far-reaching federal regula- tions since the Securities Exchange Act of 1934. It has changed the self-regulatory and peer review environment in which accounting firms had operated and has newly established auditing and related attestation, quality control, ethics, and independence standards and rules for accounting firms in the preparation and issuance of audit reports. On the side of corporate governance, the SOA mandates executive fiduciary duty, such as loans to officers and directors, management oversight, director due diligence, and executive compensation. It formally requires chief executive officers (CEOs) and chief financial officers (CFOs) to certify financial statements submitted to the U.S. Securities and Exchange Commission (SEC) and documentation of internal controls for 
the information recorded on the same statements. Section 401 of the SOA specifically commands enhanced disclosure including off-balance sheet transactions and other relationships with unconsolidated entities, not to mention the limitations on securities fraud and extended protection for whistleblowers. We revisit these important venues of research to investigate the role of financial ratios and macroeconomic indicators in predicting the changes in equity price and in capturing the regulatory effect.

A group of studies has investigated the direct impact of specific sets of financial ratios on corporate performance. Among the most popular sets of ratios are market-based ratios, such as price-to-book and price-toearnings ratios, return on earnings, dividend yield, and growth in earnings. These ratios are rooted in fundamental valuation theories and are attested to be significant determinants of corporate performance (Chan et al., 1991; Easton, 2004; Estep, 1985; Fairfield, 1994; Fama and French, 1992; Fuller and Petry, 1981; Ibbotson and Chen, 2003; Lewellen, 2004; Merton, 1973; Pontiff and Schall, 1998; Rosenberg et al., 1985; Wilcox, 1984). Another group of studies involves a different perspective that contemplates on the predictability of financial ratios in evaluating the degree of corporate failure usually termed as bankruptcy. Using a multivariate discriminant analysis in an explorative way, these studies suggest different sets of financial ratios that help predict a future event of corporate failure (Altman, 1968; Altman et al., 1994; Campbell, 1996; Mossman et al., 1998; Rushinek and Rushinek, 1987; Sori and Jalil, 2009). It is noteworthy that the second line of studies relies on methodologies that are subjective and datadriven in nature. The selection of financial ratios included is rather arbitrary as opposed to theoretical. The third group of studies explores the macroeconomic variables to establish their relation with stock returns (Bernstein and Arnott 2003; Hamburner and Kochin 1972; Ibbotson and Chen 2003; Rapach et al., 2005; Thorbecke 1997; Zhang et al., 2009). This study extends the existing literature in multiple ways: 1) we examine the predictive power of firm-specific financial ratios for corporate performance controlling for market-wide macroeconomic indicators; 2) we focus not on explaining the algebraic changes in stock prices but on predicting the directional change in stock prices; 3 ) we avoid the incompatibility problem between the firm-specific financial ratios and macroeconomic indicators by creating proxy betas for the latter; and 4) the stock price predictability of financial ratios is tested on a historic corporate event, the SOA. The objective of this study is, therefore, to examine a set of financial ratios in predicting the up or down movements of stock prices in the context of financial regulation controlling for macroeconomic variables. In the following section we deliberate on related studies. Next, the descriptions and illustrations of the sample and the empirical model (logistic regression) are provided. The empirical results and discussions follow.
Then, we conclude with a possible future research direction.

\section{RELATED STUDIES}

\subsection{Financial Ratio Variables in Prediction of Stock Returns}

Many studies report that the financial ratios, such as the book-to-market ratio (BM), earnings-to-price ratio (EP), and dividend yield (DY), and market value of equity (MVE) are significant determinants of stock returns. Fama and French (1992) challenge the norm of the time that the systematic risk of a portfolio fully explains the expected returns on securities. They present two notable results. While the cross-sectional average stock returns turn out to be a negative function of firm size (natural logarithm of market value of equity), the return sensitivity to the $\beta$ turns insignificant (we denote the firm size as "SIZE"). They further indicate that size and BM capture most of the cross-sectional variation in stock returns. Fairfield (1994) illustrates how one can substitute earnings and book value of equity for the dividends in the dividend discount model so one can focus on wealth creation as opposed to wealth distribution. In turn, earnings and book values of equity are combined into a model of BMs commingled with EPs. Since BM is associated with expected return on equity and EP with earnings growth, this joint model looks to suitably predict future profitability relative to current profitability. Berk (1995) theoretically proves that size effect is a manifestation of the risk-return structure. Kothari and Shanken (1997) investigate the return sensitivity to BM and DY using the time series of Dow Jones Industrial Average (DJIA) index and find that both ratios have strong predictive power of DJIA index returns. A bootstrapping technique confirms the results. Studying the New York Stock Exchange (NYSE)-listed equity securities, Lewellen (2004) reports similar findings. He shows that DY, BM, and EP all have significant predictive power of stock returns. A noticeable significance is found especially for DY.

Lending institutions use financial ratios to evaluate the financial health and bankruptcy potential of corporate clients. The effectiveness of financial ratios for such purpose has been ratified by multiple studies. Altman (1968) bases his bankruptcy prediction model on 22 firm-specific financial ratios and concludes that firmspecific financial ratios are a good predictor of firm's success or failure. He documents that five of the 22 financial ratios identify $94 \%$ of bankrupt firms and $97 \%$ of non-bankrupt firms. Mossman et al. (1998) perform a comparative study that scrutinizes four well-perceived prediction models and provide evidence that financial ratios are effective means of predicting bankruptcy. Rushinek and Rushinek (1987) conduct a similar study using net profit margin, times interest earned and total 
liabilities-to-total tangible net worth ratio and find that these ratios correctly categorize a sample of 30 firms into bankrupt and non-bankrupt with the success rate of $80 \%$. Working with a sample of closely held firms and a multivariate prediction model, Campbell (1996) isolates five financial ratios with which the prediction model classifies about $79 \%$ of the sample firms into the correct categories - either normal or reorganized.

\subsection{Macroeconomic Indicators in Prediction of Stock Returns}

Most market participants monitor and review macroeconomic indicators before they make an investment decision, since those indicators provide insights into the future direction of the economy. The predictive power of macroeconomic indicators on stock returns is also well documented. Fama and Schwert (1977) uncover a negative correlation between stock returns and inflation, both expected and unexpected. Chen et al. (1986) detect the significant predictive power of growth in industrial production, inflation, default risk premium and term structure on both value-weighted and equally-weighted NYSE stock returns. Campbell (1987) discusses the role of the term structure of interest rates in explaining the variation in stock returns and reports that stock returns is a function of the term structure. Fama (1990) finds that stock returns are positively and significantly associated with the default risk spread and the term structure of interest rates. Rapach et al. (2005) analyze the predictability of stock returns by macroeconomic variables, such as short-term (money market and 3-month Treasury bill) and long-term Treasury note and bond yields, term structure, inflation rate, and growth in industrial production. They show that the short-term and long-term yields are more reliable predictors of stock returns than other macroeconomic variables. Focusing on the periods of recession, Chen (2009) investigates the predictive power of a set of macroeconomic variables and presents evidence that yield spread and inflation rate are the most reliable and dominant predictors of stock returns. His results are supported by out-of-sample tests.

Some studies measure the combined effects of macroeconomic indicators and firm-specific financial ratios on stock returns. Pontiff and Schall (1998) capture the relative contributions of various macroeconomic and firm-specific ratios to stock return variability, and their results indicate that only BM and default risk premium are capable of predicting the returns of the DJIA. Specifically, the periods with higher BM and default risk premium tend to perform better than those with lower BM and default premium. Fama (1990) also identifies one financial ratio, DY, and one macroeconomic variable, default risk premium, as significant determinants of returns on the value-weighted NYSE-traded securities portfolio. Petkova (2006) compares Fama-French 3-factor model with a multivariate model with such state variables as Treasury bill rate, term structure, DY, and de- fault risk premium and shows that the latter model is superior to the former in modeling the conditional distribution of stock returns. Similarly, Zhang et al. (2009) link macroeconomic variables to two Fama-French style factors, size and BM, and find that returns on value and small stocks are a positive function of gross domestic product (GDP) growth and term structure and a negative function of inflation.

\subsection{Sarbanes-Oxley Act in Prediction of Stock Returns}

In relation to the importance of financial ratios in equity investments, there is a federal law in effect that has changed the ways of auditing, internal controls, and corporate disclosure, the SOA. The SOA was an immediate and potent reaction to a series of corporate scandals in the early 2000s, including the stunning and highly-publicized frauds at Enron, WorldCom, and Tyco. The SOA was designed to preserve auditor independence, improve corporate governance and internal control system, and enhance financial disclosure. Under the SOA, the corporate executives are in charge of providing credible financial information and accountable for any unintentional and intentional wrongdoings. Many studies report positive outcomes of the SOA. Cohen et al. (2005) and Jain et al. (2008) compare the financial scandal period with the post-SOA period. Cohen et al. (2005) show that the SOA deters the practice of earnings management that was widespread in the 2000-2001 periods. Jain et al. (2008) find evidence that the SOA improves market liquidity-i.e., narrower bid-ask spreads, higher depth, and lower adverse-selection components in the bid-ask spreads. Jain and Rezaee (2006) inspect equitymarket reactions to three types of events, ambiguous, unfavorable and favorable, leading up to the passage of the SOA and find that favorable events generate significantly positive abnormal returns, while unfavorable events bear negative abnormal returns. They conclude that the benefits of the SOA outweigh the compliance costs. Singer and You (2011) investigate the internal control requirement of Section 404 of the SOA and present evidence that the implementation of the Section improves the reliability of the corporate earnings by reducing purposeful misstatements. This improvement even enhances the relevance of current earnings to future earnings and cash flows. Brunnermeier (2005) analytically scrutinizes the impact of information asymmetry between informed and uninformed traders on informational market efficiency and shows that a regulation which intends to eliminate or alleviate the information asymmetry contributes to creating more informationefficient markets.

\subsection{Positioning the Present Study}

As described above, the existing studies about stock return prediction have compiled the separate findings in 
the context of financial ratios, macroeconomic variables, and a federal regulation (i.e., the SOA). No efforts have been made to integrate the three categories of prior studies until our current initiative. The methodological improvement in transforming the macroeconomic variables is another notable merit. By generating 10 proxy macroeconomic indicators, we avoid the problem of data incomparability between the financial ratios and the original macroeconomic variables. The current study expands the understanding of the predictive power of common firm-specific and macroeconomic variables on stock returns and discloses economic implications of federal regulation.

\section{DATA SETS AND RESEARCH MODEL CALIBRATION}

\subsection{Data Sets}

We collect the quarterly accounting and stock price information from the COMPUSTAT and calculate the various financial ratios following the definitions of the financial ratios provided in the COMPUSTAT. The total number of financial ratios is 28 , including the natural logarithm of the MVE (i.e., SIZE), and they are categorized into six different types-profitability, efficiency, rate of return, debt, management, and price ratios. Table 1 shows the full list of the financial ratios but SIZE, their types and computational definitions.

We extract the values of 10 macroeconomic indicators from the Federal Reserve Bank of St. Louis. All the variables but employment (EMPLOY) and S\&P 500 index (SP500) are seasonally adjusted. Since the financial ratios have a structure of an unbalance panel data whereas macroeconomic variables are pure time series, it is not appropriate to merge the two datasets by time order due to the incompatibility problem. Hence, we create 10 proxies for the 10 macroeconomic indicators, using a time-series rolling regression of quarterly stock returns from the COMPUSTAT on the 10 macroeconomic variables. The window of the rolling regression is 20 quarters. That is, each rolling regression requires 20 quarterly observations of the dependent and independent variables. The regression is run on each of the firms in the sample so that the firm-specific ratios have matching values of the 10 macroeconomic indicators. For example, once we run a regression of quarterly stock returns on the 10 macroeconomic variables in a quarter for a firm over the prior 20-quarter period, we obtain 10 slope coefficients of the 10 macroeconomic variables for a firm-quarter and the coefficients become the proxy macroeconomic variables for the firm-quarter. This estimation continues until the last quarter of the sample. The final sample covers 44 quarters of 16 years spanning from the first quarter of 1997 to the fourth quarter of 2007 and consists of an unbalanced panel data of 30,742 firm-quarters.

\subsection{Logistic Regression Model Calibration}

One of our main objectives is to measure the predictive power of financial ratios and macroeconomic variables in predicting the direction of stock price movements in terms of the probability of correctly forecasting the direction. Using the logistic regression model, we explore 28 financial ratios and 10 macroeconomic indicators to evaluate whether financial ratios and macroeconomic variables are useful speculative tools in equity investments. The 10 macroeconomic variables are the percentage changes in consumer price index for all urban consumers CPI, EMPLOY, real GDP, new privately owned housing units started (HOUSE), ratio of manufacturers' total inventories to shipments for all manufacturing industries (INV), money stock (M2), producer price index (PPI) for finished goods, real retail and food services sales (SALES), SP500.

Another important objective of this research is to see the overall predictive power of the financial ratios controlling for the macroeconomic variables and the change in the predictive power after the SOA, a groundbreaking enactment that changed the landscape of corporate America. Since the SOA was enacted to enhance the transparency, accountability, and confidence in corporate information, we postulate that it will also improve the accuracy and relevance of financial ratios in predicting the corporate performance and such effect will be manifested in our prediction models. To capture the impact of the SOA on the predictive power of the prediction models, we first separate the sample period into two distinct phases, pre- and post-SOA. We use 2002 as the event year that draws a line between the pre- and post-SOA phases since there was a series of bills and conferences related to the passage of the final version of the SOA between April and July of 2002. As a result, it should be considered a grey period when the effectiveness of the SOA is largely uncertain. Consequently, the pre-SOA phase includes 20 quarters of 1997 through 2001 and the post-SOA phase contains the like number of quarters of 2003 through 2007.

Considering the two main objectives, we implement the standard logistic regression as our main prediction model having the changes in the stock return, markup and markdown, as the dichotomous response variable $(Y)$ and the abovementioned set of financial ratios and proxy macroeconomic indicators as predictors $\left(x_{s}\right)$. Discriminant analysis is another popular method of predicting membership in two or more mutually exclusive groups from multiple predictors. Following Press and Wilson (1978), we utilize the logistic regression versus the discriminant analysis, since the former has fewer assumptions in theory and is more statistically robust in practice (Press and Wilson (1978) show that while both logistic regression and discriminant analysis usually reach the identical conclusions at the qualitative level, the logistic regression is more useful in a sense that it is easier to apply and interpret the results. We also 
Table 1. Descriptions of 27 financial ratios

\begin{tabular}{|c|c|}
\hline Financial ratio & Definition \\
\hline \multicolumn{2}{|l|}{ Profitability ratios } \\
\hline Net profit margin (NPM) & Income before extraordinary items/Net sales \\
\hline Pretax profit margin (PPM) & Pretax income/Net sales \\
\hline Operating profit margin after depreciation (OPMAD) & Operating income after depreciation/Net sales \\
\hline Operating profit margin before depreciation (OPMBD) & Operating income before depreciation/Net sales \\
\hline \multicolumn{2}{|c|}{ Efficiency ratios } \\
\hline Accounts receivable turnover (ARTO) & Net sales/[( Receivables $_{t}+$ Receivables $\left.\left._{t-1}\right) / 2\right]$ \\
\hline Inventory turnover (ITO) & Cost of goods sold/[(Inventories $\mathrm{t}_{\mathrm{t}}+$ Inventories $\left.\left._{\mathrm{t}-1}\right) / 2\right]$ \\
\hline Asset turnover (ATO) & Net sales/Total assets \\
\hline \multicolumn{2}{|l|}{ Rate of return measures } \\
\hline After-tax return on average common equity (ROCE) & $\begin{array}{l}\text { Income before extraordinary items adjusted for common stock equiva- } \\
\text { lents } /\left[\left(\text { Common equity }{ }_{t}+\text { Common equity }_{t-1}\right) / 2\right]\end{array}$ \\
\hline After-tax return on gross assets (ROGA) & $\begin{array}{l}\text { (Income before extraordinary items }+ \text { Interest expense)/(Total assets }+ \\
\text { Accumulated depreciation, depletion, and amortization) }\end{array}$ \\
\hline After-tax return on stockholder's equity (ROSE) & Income before extraordinary items/Stockholders' equity \\
\hline \multicolumn{2}{|l|}{ Debt ratios } \\
\hline Interest percentage of average total debt (INTTD) & $\begin{array}{l}\text { Interest expense/[(Long-term debt } t_{t}+\text { Long-term debt }_{t-1}+\text { Debt in current } \\
\left.\left.\text { liabilities }_{t}+\text { Debt in current liabilities } \text { t }_{t-1}\right) / 2\right]\end{array}$ \\
\hline Current assets to total assets (CATA) & Current assets/Total assets \\
\hline Total debt to total assets (TDTA) & (Long-term debt + Debt in current liabilities)/Total assets \\
\hline Current liabilities to total debt (CLTD) & Debt in current liabilities/(Long-term debt + Debt in current liabilities) \\
\hline Interest percentage of total liabilities (INTTL) & Interest expense/Total liabilities \\
\hline Minority percentage of total liabilities (MTL) & Minority interest/Total liabilities \\
\hline Stockholder equity percentage of total assets (SETA) & Stockholders' equity/Total assets \\
\hline Current assets to current liabilities (CACL) & Current assets/Current liabilities \\
\hline Long-term debt to common equity (LTDCE) & Long-term debt/Common equity \\
\hline Long-term debt to stockholders' equity (LTDSE) & Long-term debt/Stockholders' equity \\
\hline After-tax interest coverage (INTCOV) & (Interest expense + Income before extraordinary items)/Interest expense \\
\hline
\end{tabular}

\section{Management ratios}

Depreciation expense to property, plan, and equipment (DEPRPPT)

Dividend payout (DIVOUT)

Depreciation and amortization/Property, plan, and equipment

Cash dividends/Income before extraordinary items adjusted for common stock equivalents

\section{Price multiples}

Price to book $(\mathrm{PB})$

Year-end closing price/(Common equity/Common shares outstanding)

Price to sale (PS)

Year-end closing price/(Net sales/Common shares outstanding)

Price to earnings (PE)

Dividend yield (DY)

Year-end closing price/Earnings per share

Dividends per share by ex-date/Year-end closing price

estimate the prediction parameters using the discriminant analysis and find that the use of the discriminant analysis does not alter our main conclusions).

$$
\begin{aligned}
& Y_{i} \mid x_{1, i}, x_{2, i}, \cdots, x_{k, i} \sim B\left(p_{i}\right) \\
& E\left(Y_{i} \mid x_{1, i}, x_{2, i}, \cdots, x_{k, i}\right)=p_{i} \\
& \operatorname{Pr}\left(Y_{i} \mid x_{1, i}, x_{2, i}, \cdots, x_{k, i}\right)= \begin{cases}p_{i} & \text { if } Y_{i}=1 \\
1-p_{i} & \text { if } Y_{i}=0\end{cases} \\
& \operatorname{logit}\left[E\left(Y_{i} \mid x_{1, i}, x_{2, i}, \cdots, x_{k, i}\right)\right]=\operatorname{logit}\left(p_{i}\right)=\ln \left(\frac{p_{i}}{1-p_{i}}\right)
\end{aligned}
$$

$$
=\alpha_{0}+\beta_{1} x_{1, i}+\beta_{2} x_{2, i}+\cdots+\beta_{k} x_{k, i}
$$

where $Y_{i} \mid x_{1, i}, x_{2, i}, \cdots, x_{k, i}$ is the outcome of the response variable $(Y)$ given $k$ independent variables $\left(x_{s}\right)$ for trial $i ; B()$ is a Bernoulli distribution; $p_{i}$ is the probability of the outcome of one (i.e., a quarterly markup in stock price) against zero (i.e., a quarterly markdown in stock price); $\operatorname{Pr}\left(Y_{i} \mid x_{1, i}, x_{2, i}, \cdots, x_{k, i}\right)$ is the probability mass function of the Bernoulli distribution conditional on the independent variables with specific probabilities of the 
two possible outcomes, one and zero; $\log i t\left(p_{i}\right)=\ln \left(\frac{p_{i}}{1-p_{i}}\right)$ is the logistic regression expressed as a linear model given $p_{i}$

The beta coefficient in the logistic regression measures the change in the log odds of the response variable per unit change in the independent variable after controlling for the confounding effects of the covariates in the model. More practically, it gauges the likelihood of the response variable for a change (i.e., an increase or a decrease) in the independent variable. We especially utilize three measures of proportions, accuracy, sensitivity, and specificity to capture the SOA effect on the return predictability of the firm-specific and macroeconomic variables. We estimate those measures as follows:

$$
\begin{aligned}
& \text { Accuracy }=(\mathrm{TN}+\mathrm{TP}) /(\mathrm{TN}+\mathrm{TP}+\mathrm{FN}+\mathrm{FP}) \\
& \text { Sensitivity }=\mathrm{TP} /(\mathrm{TP}+\mathrm{FN}) \\
& \text { Specificity }=\mathrm{TN} /(\mathrm{TN}+\mathrm{FP})
\end{aligned}
$$

where TN is true negative (negative prediction turns out to be negative; correct prediction for a decrease in stock price), TP is true positive (positive prediction turns out to be positive; correct prediction for an increase in stock price), FN is false negative (negative prediction turns out to be positive; incorrect prediction for an increase in stock price), and FP is false positive (positive prediction turns out to be negative; incorrect prediction for a decrease in stock price). Accuracy is the proportion of correct predictions, either TN or TP, in a population. Sensitivity is the proportion of positive predictions that are correctly identified suggesting how good the model is at identifying stock price increases. Specificity is the proportion of negative predictions that are correctly identified. It implies how good the model is at detecting a decrease in stock price.

\section{EMPIRICAL RESULTS}

\subsection{Estimation of the SOA Effect}

We first estimate three versions of the logistic regression model with all of 28 financial ratios and 10 macroeconomic indicators that incorporate the effects of the SOA, industry, and time. The overall significance tests indicate that the logistic regression models employed are valid. The Wald, score, and likelihood tests of the general null hypothesis show that the logistic model parameters are all significant at less than onepercent level. Table 2A displays the logistic regression results before and after the SOA. The cutoff probability used for predicting whether an observation takes the value of one (increase in stock price) or not (decrease in stock price) is 0.5 . The sensitivity (the ability of the logistic model to predict an increase in stock price correctly) is $93.3 \%$ after the SOA as opposed to the corresponding sensitivity of $59.5 \%$ before the SOA. A sig- nificant improvement in predicting stock price movements is observed. The value of the specificity (the ability of the logistic model to predict a decrease in stock price correctly), however, tells a different story. The post-SOA value of $10.3 \%$ is much lower than the preSOA value of $54.1 \%$ indicating that the predictive power of the model to forecast the stock price depreciation deteriorates. The SOA appears to improve the overall forecasting accuracy from $56.9 \%$ to $58 \%$ but the improvement comes from the forecasts of stock price appreciation.

Another interesting result is that the SOA effect starts in the SOA enactment period, the period between the pre- and post-SOA periods. The SOA sensitivity and accuracy are higher than the pre- and post-SOA counterparts and the SOA specificity has the lowest value. In summary, the SOA indeed influences the forecasting

Table 2. Logistic regression results: the full set of financial ratios

Table 2A. Sarbanes-Oxley Act of 2002 (SOA) effect

\begin{tabular}{lcccc}
\hline \multicolumn{1}{c}{ Period } & No. & Accuracy & Sensitivity & Specificity \\
\hline Pre-SOA & 13,854 & 56.9 & 59.5 & 54.1 \\
SOA & 7,123 & 58.6 & 97.3 & 3.5 \\
Post-SOA & 9,755 & 58 & 93.3 & 10.3 \\
\hline
\end{tabular}

Table 2B. Industry and Sarbanes-Oxley Act of 2002 (SOA) effects

\begin{tabular}{clcccc}
\hline Industry & Period & No. & Accuracy & Sensitivity & Specificity \\
\hline 1 & Pre-SOA & 7,765 & 56.5 & 52.5 & 60.4 \\
& SOA & 3,836 & 59.3 & 95.3 & 5.2 \\
& Post-SOA & 5,177 & 57.5 & 86 & 20.6 \\
2 & Pre-SOA & 5,497 & 57.4 & 64.1 & 49.6 \\
& SOA & 2,919 & 57.8 & 92.7 & 10.3 \\
& Post-SOA & 3,921 & 59.3 & 94.8 & 9.2 \\
3 & Pre-SOA & 592 & 53.9 & 63.4 & 42.6 \\
& SOA & 368 & 53 & 57.9 & 47.8 \\
& Post-SOA & 657 & 61.5 & 78.8 & 35.8 \\
\hline
\end{tabular}

Table 2C. Time effect

\begin{tabular}{ccccc}
\hline Year & No. & Accuracy & Sensitivity & Specificity \\
\hline 1997 & 3,128 & 63.7 & 91.5 & 19.5 \\
1998 & 3,187 & 59.8 & 42.3 & 75.6 \\
1999 & 3,367 & 58.6 & 33.2 & 81.4 \\
2000 & 3,381 & 59.1 & 50.2 & 67.6 \\
2001 & 2,339 & 58.4 & 89.8 & 14.4 \\
2002 & 2,359 & 52.4 & 90 & 13.7 \\
2003 & 2,583 & 69 & 98.5 & 1.8 \\
2004 & 2,648 & 63.9 & 96.1 & 7.3 \\
2005 & 2,611 & 54.1 & 79 & 24.3 \\
2006 & 2,634 & 59.3 & 72.8 & 30.2 \\
2007 & 2,495 & 56.7 & 62.9 & 50.1 \\
\hline
\end{tabular}


ability of the stock markets. The SOA effect is positive in a sense that the overall accuracy of predicting stock price movements enhances. On the other hand, the SOA effect is very specific in a sense that the stock markets acquire a significantly higher predictive power in forecasting the stock price increase correctly but a much lower power in projecting the stock price decrease after the SOA. Two behavioral explanations for the asymmetric SOA effect between the two cases of stock changes are worth discussing. According to Einhorn and Hogarth (1986), people are susceptible to contexts and changes in such contexts in evaluating a choice or problem. In the present research, the SOA creates a new context or frame in the realm of financial reporting that might generate investors' idiosyncratic responses to the changes in the stock price. Shefrin (1999) shows how the degree of heterogeneity or dispersion in the beliefs of investors leads to the inequality between future and expected stock prices. We speculate that the asymmetric SOA effect is the manifestation of the new context and heterogeneous beliefs of investors.

\subsection{Estimation of Industry Effect and Time Effect}

Our next logistic regression adds the industry effect to the SOA effect. Industry 1 represents manufacturing firms, industry 2 contains the firms in service sectors such as transportation, communication, utility, whole sale, retail, and financial services, and industry 3 covers firms not belonging to the first two industries, for example mining, construction, and agriculture-related firms. The SOA effect still stands out in terms of the sensitivity values. For all three industries, the sensitivity significantly improves from $52.5 \%$ to $86 \%$ for industry 1 ; $64.1 \%$ to $94.8 \%$ for industry 2 ; and $63.4 \%$ to $78.8 \%$ for industry 3 . As in Table $2 \mathrm{~A}$, the specificity gets worse after the SOA across industries. Although sensitivity and specificity change in the same direction regardless of the industry type, the magnitudes of the changes vary with it. For industries 1 and 2, the post-SOA sensitivity improves by more than $30 \%$ compared to the pre-SOA sensitivity, while for industry 3 the former foreshadows the latter by about $15 \%$. Similarly, the post-SOA specificity for industry 1 and 2 weakens by about $40 \%$ in comparison with the pre-SOA specificity, but the same statistic for Industry 3 is about 7\% smaller than the preSOA figure (An anonymous reviewer raised a legitimate concern that the SOA effect would be confounded by the economic cycle. This concern is unlikely to affect our major conclusions, since according to Rapach and Zhou (2013) stock returns are more predictable during recessions than expansions).

The time effect breaks down and confirms the SOA effect. The trend in sensitivity hints that the positive SOA effect starts in 2001 (right before the enactment period) and peaks in 2003 (right after the enactment period). According to the specificity, the negative SOA effect also begins in 2001 with a specificity value of 14.4, a huge drop from 67.6 in 2000 and marks the strongest in 2003 with the lowest specificity of 1.8 . The overall accuracy measure shows that the two post-SOA years, 2003 and 2004, have the highest and second-highest values of accuracy. Table 2 send a common message that both financial ratios and macroeconomic indicators as a whole are significant predictors of stock price movements and their stock price predictability has changed after the SOA. Specifically, the SOA is positively associated with the predictability of upward stock prices and negatively with downward stock prices. In addition, the overall significant tests (Wald, score, and likelihood) for the logistic models in Table $2 \mathrm{~B}$ and $\mathrm{C}$, without exceptions, indicate that financial ratios are significant determinants of future stock prices controlling for macroeconomic indicators.

\subsection{Robustness Check: A Select Set of Predictors}

Using three variable selection processes-forward, backward, and stepwise, we single out 14 predictors out of 28 financial ratios and 10 macroeconomic indicators. This approach mitigates the potential problem of multicollinearity. We stand on the side of conservatism and select 16 predictors from the backward process instead of 14 from the forward process or 13 from the stepwise process. Notice that the majority (12) of the 16 predictors in Table 3 appear in all three processes and none of the 10 macroeconomic indicators shows up. This is a surprising outcome provided that macroeconomic indicators have attained heavy attention from most market participants-i.e., people in reality react to the upcoming and announced news on macroeconomic indicators.

Table 3. Forward, backward, and stepwise variable selection: maximum likelihood estimates

Table 3A. Forward selection process

\begin{tabular}{lcccc}
\hline Parameter & Estimate & $\begin{array}{c}\text { Standard } \\
\text { error }\end{array}$ & $\begin{array}{c}\text { Wald } \\
\text { chi-square }\end{array}$ & $\begin{array}{c}\text { pr }>\text { chi- } \\
\text { square }\end{array}$ \\
\hline Intercept & -1.4402 & 0.1469 & 96.0611 & $<0.0001$ \\
SIZE & $-6.03 \mathrm{E}-06$ & $2.94 \mathrm{E}-06$ & 4.221 & 0.0399 \\
NPM & 1.2867 & 0.3099 & 17.2423 & $<0.0001$ \\
OPMAD & -1.339 & 0.3568 & 14.0818 & 0.0002 \\
OPMBD & 0.7871 & 0.2965 & 7.0475 & 0.0079 \\
ATO & -0.2037 & 0.0629 & 10.4845 & 0.0012 \\
ROGA & -6.3795 & 1.2268 & 27.0411 & $<0.0001$ \\
CATA & -0.3308 & 0.1038 & 10.1554 & 0.0014 \\
TDTA & 1.5716 & 0.1793 & 76.8749 & $<0.0001$ \\
CLTD & 0.3742 & 0.0813 & 21.1899 & $<0.0001$ \\
INTTL & 4.9433 & 1.8187 & 7.3879 & 0.0066 \\
SETA & 1.0322 & 0.1588 & 42.2695 & $<0.0001$ \\
CACL & 0.0907 & 0.013 & 48.5454 & $<0.0001$ \\
DEPRPPT & 0.418 & 0.2151 & 3.7749 & 0.052 \\
PS & -0.0326 & 0.00295 & 122.2696 & $<0.0001$ \\
\hline
\end{tabular}

Refer to all abbreviations are listed in Table 1. 
Table 3B. Backward selection process

\begin{tabular}{lcccc}
\hline Parameter & Estimate & $\begin{array}{c}\text { Standard } \\
\text { error }\end{array}$ & $\begin{array}{c}\text { Wald } \\
\text { chi-square }\end{array}$ & $\begin{array}{c}\text { pr }>\text { chi- } \\
\text { square }\end{array}$ \\
\hline Intercept & -1.4525 & 0.1473 & 97.2719 & $<0.0001$ \\
SIZE & $-6.05 E-06$ & $2.94 \mathrm{E}-06$ & 4.2428 & 0.0394 \\
NPM & 0.9463 & 0.2329 & 16.5058 & $<0.0001$ \\
OPMAD & -1.6051 & 0.3737 & 18.4452 & $<0.0001$ \\
OPMBD & 0.8143 & 0.2955 & 7.5947 & 0.0059 \\
ATO & -0.2228 & 0.0627 & 12.6208 & 0.0004 \\
ROGA & -5.2394 & 1.0368 & 25.5388 & $<0.0001$ \\
ROSE & 0.1133 & 0.0554 & 4.1807 & 0.0409 \\
CATA & -0.346 & 0.1039 & 11.0975 & 0.0009 \\
TDTA & 1.6032 & 0.1801 & 79.2591 & $<0.0001$ \\
CLTD & 0.3787 & 0.0815 & 21.6119 & $<0.0001$ \\
INTTL & 4.8794 & 1.8263 & 7.1384 & 0.0075 \\
SETA & 1.0325 & 0.1595 & 41.8964 & $<0.0001$ \\
CACL & 0.0923 & 0.013 & 50.1391 & $<0.0001$ \\
DEPRPPT & 0.4266 & 0.2153 & 3.9269 & 0.0475 \\
PB & -0.00335 & 0.00165 & 4.1098 & 0.0426 \\
PS & -0.0307 & 0.00296 & 107.5446 & $<0.0001$ \\
\hline Ref & &
\end{tabular}

Refer to all abbreviations are listed in Table 1.

Table 3C. Stepwise selection process

\begin{tabular}{lcccc}
\hline Parameter & Estimate & $\begin{array}{c}\text { Standard } \\
\text { error }\end{array}$ & $\begin{array}{c}\text { Wald } \\
\text { chi-square }\end{array}$ & $\begin{array}{c}\text { pr }>\text { chi- } \\
\text { square }\end{array}$ \\
\hline Intercept & -1.478 & 0.1457 & 102.8738 & $<0.0001$ \\
SIZE & $-6.13 \mathrm{E}-06$ & $2.94 \mathrm{E}-06$ & 4.3597 & 0.0368 \\
NPM & 1.2605 & 0.3094 & 16.6003 & $<0.0001$ \\
OPMAD & -1.4481 & 0.3518 & 16.9481 & $<0.0001$ \\
OPMBD & 0.8869 & 0.2914 & 9.2617 & 0.0023 \\
ATO & -0.2093 & 0.0629 & 11.0805 & 0.0009 \\
ROGA & -6.1595 & 1.2191 & 25.5288 & $<0.0001$ \\
CATA & -0.3072 & 0.1031 & 8.878 & 0.0029 \\
TDTA & 1.6093 & 0.1784 & 81.4088 & $<0.0001$ \\
CLTD & 0.3924 & 0.0808 & 23.5997 & $<0.0001$ \\
INTTL & 5.1333 & 1.8313 & 7.8573 & 0.0051 \\
SETA & 1.0597 & 0.1582 & 44.856 & $<0.0001$ \\
CACL & 0.0915 & 0.013 & 49.3813 & $<0.0001$ \\
PS & -0.0322 & 0.00293 & 120.7798 & $<0.0001$ \\
\hline
\end{tabular}

Refer to all abbreviations are listed in Table 1.

We speculate that some of firm-specific financial ratios, such as size and price multiples capture the wide span of macroeconomic impact (Fama, 1990; Fama and French, 1992; Kwag and Masud, 2013). Then, we run the same sets of logistic regression models as the ones in Table 2 and report the overall accuracy, sensitivity, and specificity together with SOA, industry, and time effects in Table 4. The results are nearly identical to those of the logistic regressions including all of financial ratios and macroeconomic indicators and no further discussion is necessary.
Table 4. Logistic regression results: a select set of financial ratios

Table 4A. Sarbanes-Oxley Act of 2002 (SOA) effect

\begin{tabular}{lcccc}
\hline \multicolumn{1}{c}{ Period } & No. & Accuracy & Sensitivity & Specificity \\
\hline Pre-SOA & 13,854 & 56.5 & 59.1 & 53.7 \\
SOA & 7,123 & 58.5 & 97.6 & 3 \\
Post-SOA & 9,755 & 58.3 & 94.4 & 9.3 \\
\hline
\end{tabular}

Table 4B. Industry and Sarbanes-Oxley Act of 2002 (SOA) effect

\begin{tabular}{|c|c|c|c|c|c|}
\hline $\begin{array}{c}\text { Industry } \\
\text { ID }\end{array}$ & Period & No. & Accuracy & Sensitivity & Specificity \\
\hline \multirow[t]{3}{*}{1} & Pre-SOA & 7,765 & 56.1 & 51 & 61.1 \\
\hline & SOA & 3,836 & 59.9 & 97.7 & 3 \\
\hline & Post-SOA & 5,177 & 57.2 & 88.4 & 16.6 \\
\hline \multirow[t]{3}{*}{2} & Pre-SOA & 5,497 & 57.2 & 64.1 & 49.4 \\
\hline & SOA & 2,919 & 57.6 & 98 & 2.4 \\
\hline & Post-SOA & 3,921 & 59.3 & 96.2 & 7.2 \\
\hline \multirow[t]{3}{*}{3} & Pre-SOA & 592 & 54.7 & 69.9 & 36.7 \\
\hline & SOA & 368 & 58.7 & 60 & 57.3 \\
\hline & Post-SOA & 657 & 62.3 & 86.5 & 26.4 \\
\hline
\end{tabular}

Table 4C. Time effect

\begin{tabular}{ccccc}
\hline Year & No. & Accuracy & Sensitivity & Specificity \\
\hline 1997 & 3,128 & 61.4 & 95.9 & 6.8 \\
1998 & 3,187 & 57.2 & 35.5 & 76.7 \\
1999 & 3,367 & 56.8 & 26.4 & 84 \\
2000 & 3,381 & 57.5 & 45.4 & 69.1 \\
2001 & 2,339 & 59.1 & 85.5 & 23.2 \\
2002 & 2,359 & 52.1 & 92.2 & 17.7 \\
2003 & 2,583 & 69.3 & 99.6 & 0.1 \\
2004 & 2,648 & 64.2 & 97.4 & 5.8 \\
2005 & 2,611 & 54.7 & 92.4 & 12.7 \\
2006 & 2,634 & 59.7 & 78.5 & 11.2 \\
2007 & 2,495 & 57 & 61.1 & 52.7 \\
\hline
\end{tabular}

\section{CONCLUSIONS AND FUTURE RESEARCH}

The present study revisits a well-established research field of financial ratios and macroeconomic indicators and proposes two testable hypotheses. Using the logistic regression, we convey two major messages: 1) financial ratios are meaningful predictors of stock price changes and subdue the influence of macroeconomic indicators on such changes; and 2) more importantly, the SOA truly improves the stock price predictability of financial ratios for the markup sample. It is also noteworthy of two minor but intriguing findings: 1) industry and time effects exist; and 2) for the markdown sample, the SOA actually deteriorates the predictive power of financial ratios. From the behavioral perspective, the latter minor finding warrants future research. 


\section{REFERENCES}

Altman, E. I. (1968), Financial ratios, discriminant analysis and the prediction of corporate bankruptcy, Journal of Finance, 23(4), 589-609.

Altman, E. I., Marco, G., and Varetto, F. (1994), Corporate distress diagnosis: comparisons using linear discriminant analysis and neural networks (the Italian experience), Journal of Banking and Finance, 18(3), 505-529.

Berk, J. B. (1995), A critique of size-related anomalies, Review of Financial Studies, 8(2), 275-286.

Bernstein, W. J. and Arnott, R. D. (2003), Earnings growth: the two percent dilution, Financial Analysts Journal, 59(5), 47-55.

Brunnermeier, M. K. (2005), Information leakage and market efficiency, Review of Financial Studies, 18 (2), 417-457.

Campbell, J. Y. (1987), Stock returns and the term structure, Journal of Financial Economics, 18(2), 373399.

Campbell, J. Y. (1996), Understanding risk and return, Journal of Political Economy, 104(2), 298-345.

Chan, L. K., Hamao, Y., and Lakonishok, J. (1991), Fundamentals and stock returns in Japan, Journal of Finance, 46(5), 1739-1764.

Chen, N. F., Roll, R., and Ross, S. A. (1986), Economic forces and the stock market, Journal of Business, 59(3), 383-403.

Chen, S. S. (2009), Predicting the bear stock market: macroeconomic variables as leading indicators, Journal of Banking and Finance, 33(2), 211-223.

Cohen, D. A., Dey, A., and Lys, T. Z. (2005), Trends in earnings management and informativeness of earnings announcements in the pre- and post-Sarbanes Oxley periods, Working paper, Northwestern University, Evanstron, IL.

Easton, P. D. (2004), PE ratios, PEG ratios, and estimating the implied expected rate of return on equity capital, The Accounting Review, 79(1), 73-95.

Einhorn, H. J. and Hogarth, R. M. (1986), Decision making under ambiguity, Journal of Business, 59(4), S225-S250.

Estep, P. W. (1985), A new method for valuing common stocks, Financial Analysts Journal, 41(6), 26-33.

Fairfield, P. M. (1994), P/E, P/B and the present value of future dividends, Financial Analysts Journal, 50(4), 23-31.

Fama, E. F. (1990), Stock returns, expected returns, and real activity, Journal of Finance, 45(4), 1089-1108.

Fama, E. F. and French, K. R. (1992), The cross-section of expected stock returns, Journal of Finance, 47 (2), 427-465.

Fama, E. F. and Schwert, G. W. (1977), Asset returns and inflation, Journal of Financial Economics, 5(2),
115-146.

Fuller, R. J. and Petry, G. H. (1981), Inflation, return on equity, and stock prices, Journal of Portfolio Management, 7(4), 19-25.

Hamburger, M. J. and Kochin, L. A. (1972), Money and stock prices: the channels of influence, Journal of Finance, 27(2), 231-249.

Ibbotson, R. G. and Chen, P. (2003), Long-run stock returns: participating in the real economy, Financial Analysts Journal, 59(1), 88-98.

Jain, P. K. and Rezaee, Z. (2006), The Sarbanes-Oxley Act of 2002 and capital-market behavior: early evidence, Contemporary Accounting Research, 23(3), 629-654.

Jain, P. K., Kim, J. C., amd Rezaee, Z. (2008), The Sarbanes-Oxley Act of 2002 and market liquidity, $\mathrm{Fi}$ nancial Review, 43(3), 361-382.

Kothari, S. P. and Shanken, J. (1997), Book-to-market, dividend yield, and expected market returns: a time-series analysis, Journal of Financial Economics, 44(2), 169-203.

Kwag, S. W. and Masud, A. A. (2013), Modeling and predicting stock returns: the rule of parsimony, Working paper, Sookmyung Women's University, Seoul, Korea.

Lewellen, J. (2004), Predicting returns with financial ratios, Journal of Financial Economics, 74(2), 209235.

Merton, R. C. (1973), An intertemporal capital asset pricing model, Econometrica, 41(5), 867-887.

Mossman, C. E., Bell, G. G., Swartz, L. M., and Turtle, H. (1998), An empirical comparison of bankruptcy models, Financial Review, 33(2), 35-54.

Petkova, R. (2006), Do the Fama-French factors proxy for innovations in predictive variables? Journal of Finance, 61(2), 581-612.

Pontiff, J. and Schall, L. D. (1998), Book-to-market ratios as predictors of market returns, Journal of Financial Economics, 49(2), 141-160.

Press, S. J. and Wilson, S. (1978), Choosing between logistic regression and discriminant analysis, Journal of the American Statistical Association, 73(364), 699-705.

Rapach, D. and Zhou, G. (2013), Forecasting stock returns. In: Elliott, G. and Timmermann, A. (eds.), Handbook of Economic Forecasting volume 2, North-Holland, Amsterdam, the Netherlands, 327383.

Rapach, D. E., Wohar, M. E., and Rangvid, J. (2005), Macro variables and international stock return predictability, International Journal of Forecasting, 21(1), 137-166.

Rosenberg, B., Reid, K., and Lanstein, R. (1985), Persuasive evidence of market inefficiency, Journal of Portfolio Management, 11(3), 9-16. 
Rushinek, A. and Rushinek, S. F. (1987), Using financial ratios to predict insolvency, Journal of Business Research, 15(1), 93-100.

Shefrin, H. (1999), Irrational exuberance and option smiles, Financial Analysts Journal, 55(6), 91-103.

Singer, Z. and You, H. (2011), The effect of Section 404 of the Sarbanes-Oxley Act on earnings quality, Journal of Accounting, Auditing and Finance, 26 (3), 556-589.

Sori, Z. M. and Jalil, H. A. (2009), Financial ratios, discriminant analysis and the prediction of corporate distress, Journal of Money, Investment and Banking, 11, 5-15.

Thorbecke, W. (1997), On stock market returns and monetary policy, Journal of Finance, 52(2), 635654.

Wilcox, J. W. (1984), The P/B-ROE valuation model, Financial Analysts Journal, 40(1), 58-66.

Zhang, Q. J., Hopkins, P., Satchell, S., and Schwob, R. (2009), The link between macro-economic factors and style returns, Journal of Asset Management, 10(5), 338-355. 